\title{
THE FORMS OF WATER: in the land and in the soul
}

\section{Transforming Cultures eJournal, \\ Vol. 1 No. 2, June 2006 \\ http://epress.lib.uts.edu.au/journals/TfC}

\section{Jeff Malpas \\ Tasmania}

Water, its presence or absence, and the forms in which it appears, is fundamental to any and every place on earth. Indeed, along with soil, air and light, water is elemental to place, and so also to all life and dwelling in place. Moreover, human life is itself essentially determined through its entanglement in place and places, and so is constituted, if indirectly, perhaps, through water and its forms. The centrality of place that I am alluding to here arises out of a conception of the relation between human being and place, according to which who and what we are is fundamentally determined by the places in which we live - and this is so even while places are also shaped by the lives that are formed within them.

The idea that human life and being may be bound to place in this way is a common theme in much contemporary thought and practice from anthropology and geography to art and architecture. ${ }^{1}$ The idea of a close connection between human life and land is especially prominent, of course, in the thinking of many indigenous cultures - in, for instance, that of North American Indian as well as of Australian Aboriginal peoples ${ }^{2}-$

\footnotetext{
${ }^{1}$ It would a difficult and lengthy task to try to list all of the works that have appeared in recent years on this subject, but such a list would include, among many others, works such as: Paul C. Adams (ed.) (2001) The Textures of Place: Exploring Humanist Geographies, University of Minnesota Press; Edward S. Casey (1999) The Fate of Place, Berkeley: University of California Press; Tacita Dean and Jeremy Millar (2005) Place, Artworks Series, London: Thames and Hudson; Nicholas Entrikin (1991) The Betweenness of Place, Baltimore: Johns Hopkins University Press; Steven Feld \& Keith Basso (eds.) (1997) Senses of Place, School of American Research Press; Karsten Harries (1998) The Ethical Function of Architecture, Cambridge Mass.: MIT Press; Dolores Hayden (1995) The Power of Place: Urban Landscapes as Public History, Cambridge Mass.: MIT Press; J. B. Jackson (1996) A Sense of Place, A Sense of Time, Yale University Press; Peter Read (2000) Belonging: Australians, Place and Aboriginal Ownership, Cambridge: Cambridge University Press; Edward Relph (1976) Place and Placelessness, London: Routledge \& Kegan Paul; David Seamon \& Robert Mugerauer (eds.) (1989) Dwelling, Place and Environment: Towards a Phenomenology of Person and World, New York: Columbia University Press; Yi-Fu Tuan (1990) Topophilia, New York: Columbia University Press.

2 See Fred R Myers' (1991) classic Pintupi Country, Pintupi Self: Sentiment, Place and Politics among Western Desert Aborigines, Berkeley: University of California Press; and also Deborah Bird Rose (1991)
} 
but it is not a feature of indigenous culture alone. Not only is the idea of such a connection quite widespread in a way that is independent of culture and history, but there is good reason to suppose that our being bound to place is an essential feature of our being human. The evidence to support such a view is various, but depends essentially on recognising the way in which our identities are dependent on the possibilities of action that are available to us and the way those possibilities for action are themselves dependent on the spatio-temporalised forms of our immediate environment. ${ }^{3}$ Put simply: what we are depends on what we can do, and what we can do depends on where we are situated. It is not merely, then, that we look to the places in which we live as that by means of which we explicitly articulate a sense of ourselves, but more than this, the very shape of our lives is determined, implicitly and explicitly, by the possibilities that are given in and through the places which we live and our interaction with those possibilities and places.

I have used the term 'topography' to describe the particular mode of inquiry, as well as method, that takes such constitution of the human in relation to place as a central theme. ${ }^{4}$ Of course, the idea of topography itself calls upon the notion of place, of topos, and so my claim is not only that we are ourselves constituted in and through place, but that the relations involved here are themselves essentially the relations exemplified in the structure of place. Place thus provides a twofold key to understanding the constitution of human life, and, more broadly, of how the world within that life appears.

But how does place appear, in what forms, and how do places themselves structure themselves? These sorts of question can be addressed at a number of different levels. For instance, at one level, a more abstract level, I would argue that places are structured and articulated in and through narrative - though I would need to say a fair bit about what narrative means here. ${ }^{5}$ At another level, places are essentially understood through ideas of pathway and track, of border and crossing, of site and situation. And at yet

Dingo Makes Us Human: Life and Land in an Australian Aboriginal Culture, Cambridge: Cambridge University Press.

${ }^{3}$ See my (1999) Place and Experience, Cambridge: Cambridge University Press.

${ }^{4}$ See Malpas (1999:39-41) and my discussion in Heidegger's Topology: Being, Place, World, Cambridge, Mass.: MIT Press, (2005, forthcoming).

${ }^{5}$ See, once again, Malpas (1999:179-87). I take narrative to include not only explicitly presented narratives that appear in the form of stories that are told to be heard or read, but also the implicit narratives encoded in patterns of action or the layout of a particular space. 
another level again, our thinking about place takes shape in our thinking about various 'features' or 'elements' of place - building and street, bridge and road, earth and sky, hill and mountain, valley and plain, river and lake, swamp and floodplain, estuary, coast and sea.

It is when we look to these latter elements that the fundamental role of water in place comes to light. It is through the forms of water, as also through the forms of earth, light and air, that places come to have the particular character that belongs to them. Indeed, reflecting on Veronica Strang's pioneering investigation of the 'meaning' of water, ${ }^{6}$ we may say that the meaning of place is itself significantly constituted through the meaning - and meanings - of water. Moreover, while the various forms of water contribute to the constitution of different places, perhaps the role of water as a basic and determining element of place should also be seen to determine places as themselves essentially fluid and dynamic.

The various forms of water at issue here have to be understood in terms of the way those forms shape kinds of actions and modes of agency. This is evident, for instance, in the contrast, especially important in Indigenous cultures in northern Australia, between saltwater and fresh. ${ }^{7}$ We may think of these as constituting two entirely different 'worlds', but if we do, then we must think of these different worlds as coalescing around different modes of living, acting, moving as these are associated with coast and sea, river, creek and waterhole. Similarly, the contrast between water that is temporary and permanent, also important in Indigenous culture and thought, brings with it different modes of living through the different forms of movement and action that arise in relation to each of these.

Particular forms of water, and not only these contrasting 'worlds', are similarly tied to different formations of place. The river, for instance, functions as a boundary, as well as a point of crossing over (indeed, the way water functions to mark transition is an important feature of the way water presents itself in almost all its forms); it is also a means of transportation, and so a means of connection as well as separation. As boundary and connection, as highway and divide, the river constitutes places in and

\footnotetext{
${ }^{6}$ Veronica Strang (2004) The Meaning of Water, Oxford: Berg.

${ }^{7}$ See Nonie Sharp (2002) Saltwater People: the Waves of Memory, Crows Nest, NSW: Allen \& Unwin.
} 
around it in particular ways that are directly determined by the shaping of agency and movement. The sea also functions as both boundary and highway, and like the river, it constitutes its own place. But inasmuch as sea stands in contrast to the land, as salt stands in contrast to fresh, so the sea stands in opposition to the land as another realm with its own ordering, its own resources, its own threats and bounties, its own cycles, movements and patterns of activity. These various forms of water, salt and fresh, transient and permanent, sea and river, are articulated through the actions and movements correlated with them, but those actions and movements, and so the character of those forms of water, and their places, are also articulated through narrative, story, myth, metaphor and image. Moreover, this is not merely a feature of indigenous understanding, but of understanding as such - our connectedness to place, and the character of place, is worked out through narrative, and in those narratives of place, narratives of water play as central a role as the forms of water play in the constitution of place.

As the forms of water determine the identity of places, so they also determine identity as such. We can see this at work in a host of different instances and examples. In Europe, rivers have played a central role in the constitution, not only of the European landscape, or even of European regions and nations, but of European identity as such. Thus, in the work of Friedrich Hölderlin, we find poetic meditations on the Danube, also called the Ister and the Donau (the variation in names tells us something about the different faces of the river), as well as the Rhine, as they stand in relation to the idea of Germany and of German culture. ${ }^{8}$ The Danube, in particular, appears in Hölderlin as the conduit that brings Germany into its own through bringing Germany into conjunction with its other, namely, the Greek - the Danube connects occidental and oriental, the domestic and the foreign. ${ }^{9}$

The role played by the Danube and the Rhine in Europe is not obviously replicated in Australia. George Seddon writes that "The Nile, the Rhine, Ganges, Mississippi all have a historical, social, economic and political significance. The only river in Australia of which that can be said is the Murray. Australia is organised around ports, roads and rail,

\footnotetext{
${ }^{8}$ See The Rhein [Der Rhein]', 'The Ister [Der Ister]', in Hymns and Fragments by Friedrich Hölderlin, (1984) trans. Richard Sieburth, Princeton: Princeton University Press.

${ }^{9}$ See Julian Young's useful discussion of Heidegger and Hölderlin in "Poets and Rivers: Heidegger on Hölderlin's Der Ister”, Dialogue 28 (1999:391-416).
} 
not along rivers". ${ }^{10}$ Seddon is right that rivers do not have the same role in the constitution of Australian places - the Murray is the obvious and perhaps solitary exception here ${ }^{11}$ - and so also Australian culture and identity, as do the Rhine, the Nile or indeed the Danube. And while ports, roads and rail have an obvious significance in Australian life, I would argue that the different forms of water to be found in the Australia as opposed to, for example, Europe, are just as important in making Australian places and Australian life.

Water does not figure in the constitution of places only as a feature of the land - river, lake, swamp and so forth - nor only in its contrasting form as sea, but also in its appearance as a feature of the sky - as mist, rain (in all its varieties), sleet, snow, and, one must also say, as drought. Indeed, in many Australian places, in fact, the appearance of water in its cyclical, seasonal variability is a key aspect of the way water appears and so of the way the place is determined. Indeed, to some extent this embodied in indigenous thinking in the form of the water-spirit that is the rainbow serpent who not only forms springs and waterholes by his movements across the land, but also alternates between activity and rest, abundance and scarcity.

It is easy to overlook the forms of water that are associated with the seasons, and so also with the sky. Yet these forms can be just as important as those forms that appear on the land or as the sea. Think of the difference between the misty, rain-soaked Irish landscape and the tropical world of torrential rains and humidity that is to be found in parts of Northern Australia. Indeed, the ways in which water appears in the air and through the forms of weather, and not only as a feature of the earth and land, reinforces the key role of water as an element in place. Yet it also indicates the extent to which human engagement with water occurs at a very basic experiential level. We feel water through all of our senses: when we feel the wetness of mist on our skin, when we breathe in the humidity of a tropical evening, when we see the refraction of light through water droplets in a rainbow, when we hear the fall of rain on a tin roof. ${ }^{12}$

\footnotetext{
${ }^{10}$ George Seddon (1998) “A Snowy River Reader”, Landprints, Cambridge: Cambridge University Press, p.51.

${ }^{11}$ See Paul Sinclair's study of the Murray (2001) The Murray: A River and its People, Melbourne: Melbourne University Press.

${ }^{12}$ See Strang's discussion of the sensory experience of water and its interpretations (2004:49-79).
} 
The different forms of water are constitutive of the character of different places. Yet as places are constitutive of our own identity - we are who and what we are in and through the places we inhabit - so the forms of water enter into and are constitutive of the soul no less than of the land and the place. In drinking, bathing, and in all the various uses to which water is put, then, not only do we not satisfy certain basic physiological and practical needs, not only do we draw upon an element of the natural environment, but we also enact and reinforce the fundamental relatedness that obtains between us and the place and places in which we dwell. To think through the significance of water in human life thus involves more than just considerations of health or of economics - it touches on our very constitution as human, since it touches on our constitution in and through place.

Here, I suggest, is the real core of the idea of water as a 'commons' - the 'commons' is not just that which is common to all as some sort of shared possession, but rather that which is common in such a way that all partake of it, all are determined by it, all are already given over to caring for it, just insofar as they are already given over to caring for themselves. This is why the Cochabamba Declaration made by the indigenous people of Bolivia in December 2000 rightly takes as its first statement not merely a statement concerning water as a physical necessity for life, but concerning water as scared to life: "Water belongs to the earth and all species and is sacred to life". ${ }^{13}$ It is the sacredness of water which is taken as the basis for the imperative to conserve, reclaim and protect it.

\footnotetext{
${ }^{13}$ The Cochabamba Declaration, made on 8 December 2000, in Cochabamba, Bolivia:

"We, citizens of Bolivia, Canada, United States, India, Brazil: Farmers, workers, indigenous people, students, professionals, environmentalists, educators, nongovernmental organizations, retired people, gather together today in solidarity to combine forces in the defence of the vital right to water.

Here, in this city which has been an inspiration to the world for its retaking of that right through civil action, courage and sacrifice standing as heroes and heroines against corporate, institutional and governmental abuse, and trade agreements which destroy that right, in use of our freedom and dignity, we declare the following: For the right to life, for the respect of nature and the uses and traditions of our ancestors and our peoples, for all time the following shall be declared as inviolable rights with regard to the uses of water given us by the earth:

1. Water belongs to the earth and all species and is sacred to life, therefore, the world's water must be conserved, reclaimed and protected for all future generations and its natural patterns respected.

2. Water is a fundamental human right and a public trust to be guarded by all levels of government, therefore, it should not be commodified, privatized or traded for commercial purposes. These rights must be enshrined at all levels of government. In particular, an international treaty must ensure these principles are noncontrovertable.

3. Water is best protected by local communities and citizens who must be respected as equal partners with governments in the protection and regulation of water. Peoples of the earth are the only vehicle to promote earth democracy and save water."
} 
The second sense of 'commons' that is at issue here is, it seems to me, often overlooked or ignored in favour of the more pragmatic, instrumentalist conception of the 'commons' as some form of common 'property' or 'resource'. We might distinguish between these two senses of 'commons' in terms that also mirror two different senses in which we may also understand our relation to land or to place: as that which belongs to us or as that to which we belong. It is this second sense that, I would suggest, is the more fundamental.

The experience of water, or of the forms of water, and of the relation between water and the other elements of place, is a central element in the experience of place as such, and so also of the experience of ourselves and the world. Water is an increasingly important focus for political and environmental concerns, but water is not merely a commodity or a resource to be used and managed - not even when the management is ecologically sensitive. Water is more than just a commodity or resource. To attune ourselves to our essential inter-relatedness to place, and our own entanglement in it, to attune ourselves to the 'spirit' of place, is also to attune ourselves to the 'spirit' of water and to its forms.

\section{References}

Adams, P.C. (ed.) (2001) The Textures of Place: Exploring Humanist Geographies, University of Minnesota Press.

Casey, E.S. (1999) The Fate of Place, Berkeley: University of California Press.

Dean, T. \& Millar, J. (2005) Place, Artworks Series, London: Thames and Hudson.

Entrikin, N. (1991) The Betweenness of Place, Baltimore: Johns Hopkins University Press.

Feld, S. \& Basso, K. (eds.) (1997) Senses of Place, School of American Research Press.

Harries, K. (1998) The Ethical Function of Architecture, Cambridge Mass.: MIT Press.

Hayden, D. (1995) The Power of Place: Urban Landscapes as Public History, Cambridge Mass.: MIT Press.

Jackson, J.B. (1996) A Sense of Place, A Sense of Time, Yale University Press.

Malpas, J. (1999) Place and Experience, Cambridge: Cambridge University Press. (2005, forthcoming) Heidegger's Topology: Being, Place, World, Cambridge, Mass.: MIT Press. 
Myers, F.R. (1991) Pintupi Country, Pintupi Self: Sentiment, Place and Politics among Western Desert Aborigines, Berkeley: University of California Press.

Read, P. (2000) Belonging: Australians, Place and Aboriginal Ownership, Cambridge: Cambridge University Press.

Relph, E. (1976) Place and Placelessness, London: Routledge \& Kegan Paul.

Rose, D.B. (1991) Dingo Makes Us Human: Life and Land in an Australian Aboriginal Culture, Cambridge: Cambridge University Press.

Seamon, D. \& Mugerauer, R. (eds.) (1989) Dwelling, Place and Environment: Towards a Phenomenology of Person and World, New York: Columbia University Press.

Seddon, G. (1998) “A Snowy River Reader”, Landprints, Cambridge: Cambridge University Press.

Sharp, N. (2002) Saltwater People: the Waves of Memory, Crows Nest, NSW: Allen \& Unwin.

Sieburth, R. (trans.) (1984) Hymns and Fragments by Friedrich Hölderlin, Princeton: Princeton University Press.

Sinclair, P. (2001) The Murray: A River and its People, Melbourne: Melbourne University Press.

Strang, V. (2004) The Meaning of Water, Oxford: Berg.

Tuan, Y-F. (1990) Topophilia, New York: Columbia University Press.

Young, J. (1999) “Poets and Rivers: Heidegger on Hölderlin’s Der Ister”, Dialogue 28. 